\title{
The use of perioperative serial blood lactate levels, the APACHE II and the postoperative MELD as predictors of early mortality after liver transplantation ${ }^{1}$
}

\author{
O uso da dosagem seriada do lactato sérico no perioperatório, do APACHE II e do MELD pós- \\ operatório como preditores de mortalidade precoce após transplante hepático
}

\begin{abstract}
Anibal Basile-Filho , Edson Antonio Nicolini", Maria Auxiliadora-Martins ${ }^{\mathrm{III}}$, Orlando de Castro e Silva Jr ${ }^{\mathrm{IV}}$
I PhD, Associate Professor, Head of Division of Intensive Care, Department of Surgery and Anatomy, FMRP-USP, Ribeirao Preto-SP, Brazil. Responsible for design, intellectual and scientific content, English language of the study.

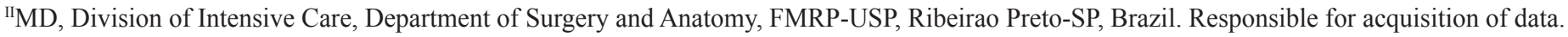

IIIPhD, Affiliate Professor, Division of Intensive Care, Department of Surgery and Anatomy, FMRP-USP, Ribeirao Preto-SP, Brazil. Responsible for acquisition of data, critical review of the manuscript.

${ }^{\text {IV }} \mathrm{PhD}$, Chairman and Head, Division of Digestive Surgery and Liver Transplantation Program, Department of Surgery and Anatomy, FMRP-USP, Ribeirao Preto-SP, Brazil. Responsible for technical procedures of liver transplantation.
\end{abstract}

\begin{abstract}
PURPOSE: To evaluate the accuracy of different parameters in predicting early (one-month) mortality of patients submitted to orthotopic liver transplantation (OLT).

METHODS: This is a retrospective study of forty-four patients (38 males and 10 females, mean age of $52.2 \pm 8.9$ years) admitted to the Intensive Care Unit of a tertiary hospital. Serial lactate blood levels, APACHE II, MELD post-OLT, creatinine, bilirubin and INR parameters were analyzed by receiver-operator characteristic (ROC) curves as evidenced by the area under the curve (AUC). The level of significance was set at 0.05 .

RESULTS: The mortality of OLT patients within one month was $17.3 \%$. Differences in blood lactate levels became statistically significant between survivors and nonsurvivors at the end of the surgery $(\mathrm{p}<0.05)$. The AUC was $0.726(95 \% \mathrm{CI}=0.593-0.835)$ for APACHE II $(\mathrm{p}=0.02) ; 0.770(95 \% \mathrm{CI}=0.596-0.849)$ for blood lactate levels (L7-L8) $(\mathrm{p}=0.03)$; 0.814 (95\%CI = 0.690-0.904) for MELD post-OLT $(\mathrm{p}<0.01) ; 0.550(95 \% \mathrm{CI}=0.414-0.651)$ for creatinine $(\mathrm{p}=0.64) ; 0.705(95 \% \mathrm{CI}=0.571-0.818)$ for bilirubin $(\mathrm{p}=$ $0.05)$ and $0.774(95 \% \mathrm{CI}=0.654-0.873)$ for INR $(\mathrm{p}=0.02)$.
\end{abstract}

CONCLUSION: Among the studied parameters, MELD post-OLT was more effective in predicting early mortality after OLT.

Keywords: Lactic Acid. Liver Transplantation. Severity of Illness Index. Prognosis.

\section{RESUMO}

OBJETIVO: Avaliar qual parâmetro é o mais eficiente na predição de mortalidade precoce (um mês) de pacientes submetidos a transplante ortotópico de fígado (OLT).

MÉTODOS: Estudo retrospectivo em cinqüenta e oito pacientes adultos (44 homens e 14 mulheres, com uma idade média de $51,7 \pm$ 10,1 anos) admitidos na Unidade de Terapia Intensiva de um hospital terciário. Os parâmetros como a dosagem seriada de lactato no sangue, APACHE II, MELD pós-OLT, creatinina, bilirrubina e INR foram analisados por curvas ROC (Receiver-operator characteristic), evidenciado pela área abaixo da curva (AUC). O nível de significância foi definido em 0,05 .

RESULTADOS: A mortalidade dos pacientes OLT em até um mês foi de 17,3\%. As diferenças no nível de lactato no sangue tornaramse estatisticamente significantes entre sobreviventes e não sobreviventes no final da cirurgia $(\mathrm{p}<0,05)$. A AUC foi de $0,726(95 \% \mathrm{CI}$ $=0,593-0,835)$ para APACHE II $(\mathrm{p}=0,02) ; 0,770(95 \% \mathrm{CI}=0,596-0,849)$ para o lactato sérico $(\mathrm{L} 7-\mathrm{L} 8)(\mathrm{p}=0,03) ; 0,814(95 \% \mathrm{CI}=$ 0,690-0,904) para MELD post-OLT $(\mathrm{p}<0,01) ; 0,550(95 \% \mathrm{CI}=0,414-0,651)$ de creatinina $(\mathrm{p}=0,64) ; 0,705(95 \% \mathrm{CI}=0,571-0,818)$ de bilirrubina $(\mathrm{p}=0,05)$ e $0,774(95 \% \mathrm{CI}=0,654-0,873)$ para INR $(\mathrm{p}=0,02)$.

CONCLUSÃO: Dentre os vários parâmetros estudados, o MELD pós-OLT foi o mais eficaz na predição de mortalidade precoce em pacientes submetidos à OLT.

Descritores: Ácido Láctico. Transplante de Fígado. Índice de Gravidade de Doença. Prognóstico. 


\section{Introduction}

The outcome of patients submitted to orthotopic liver transplantation (OLT) does not depend only on the quality of the graft, cold ischemia time and the medical condition of the recipient prior to the surgery. The posttransplantation outcome is also affected by perioperative and the immediate postoperative care delivered to the patient, at the Intensive Care Unit (ICU) arrival. Because of the set of procedures involved in OLT is highly complex, it is important that the factors influencing the morbidity/ mortality of OLT patients in the short-term are determined.

Several studies have been conducted in an attempt to find an ideal parameter that employs clinical symptoms or comorbidities and that can accurately predict postoperative complications. Among these predictors serial perioperative blood lactate has been proposed to investigate the graft function and its hability to reduce lactate levels ${ }^{1,2}$. Furthermore, other predictors were also utilized such as international normalized ratio (INR) ${ }^{3}$, Acute Physiology and Chronic Health Evaluation II (APACHE II) and postoperative Model of Ende-stage Liver Disease (MELD) ${ }^{4}$.

The aim of the present study was to investigate which parameter (Serial lactate blood levels, APACHE II, postoperative MELD, creatinine, bilirubin and INR) is the most effective in predicting early mortality (up to 30 post transplantation days) of patients submitted to OLT.

\section{Methods}

This is a retrospective study conducted in the Intensive Care Unit (ICU) of Clinics Hospital of Ribeirão Preto Medical School of the University of São Paulo, Brazil. The research protocol was approved by the Research Ethics Committee of the Clinics Hospital of Ribeirão Preto Medical School of the University of São Paulo.

Fifty-eight adult patients (44 males and 14 females, with a mean age of $51.7 \pm 10.1$ years) admitted to the ICU during the immediate OLT postoperative period were included in the study. The OLT procedures were performed between 2008 and 2010. Exclusion criteria included fulminant acute hepatitis and familial amyloid polyneuropathy. The type of condition (demographic, clinical data and scores) was observed by comparison of groups of patients designated survivors and nonsurvivors. Various indexes were employed for prediction of early mortality (up to 30 posttransplantation days). Serial blood lactate levels was performed at preoperative phase or baseline (L1), every 60-90 minutes (L2-L6) from the beginning of surgery, at the end of surgery (reperfusion) of the graft (L7-L8), 24 and 48 hours after the surgery (D1 and D2, respectively). The Data for calculation of the APACHE II score and the postoperative MELD (MELD Post-OLT) were collected during the first 24 hours after patient admission. The APACHE II scoring system takes account of 12 physiological variables, as well as Glasgow coma scale, age, occurrence of urgent surgical procedures, and comorbidities, as originally described by Knaus et al. ${ }^{5}$. MELD score was determined after OLT (MELD post-OLT), by means of the following equation: $\mathrm{MELD}=0.957 \times \log _{\mathrm{e}}\left(\right.$ Creatinine $\left.{ }^{*}\right)+0.378 \mathrm{x}$ $\log _{e}($ Bilirubin* $)+1.12 x \log _{e}($ INR $)+0.643$

*Creatinine and Bilirubin are expressed in $\mathrm{mg} / \mathrm{dL}$.

\section{Statistical analysis}

An unpaired Student $t$ test was used to compare differences between demographic and clinical data of patients. The values were reported as mean \pm standard deviation (SD). The variables at admission such as APACHE II, MELD post-OLT, creatinine, bilirubin, INR, and blood lactate levels L7-L8 were analysed by generation of receiver operating characteristics (ROC) curves to determine the area of the ROC curve (AUC), as predictive factor for each parameter. The significance was tested using Wilcoxon test $^{6}$. The serial blood lactate levels (from baseline to D2) were performed by adjusting a random effect model and, the differences between the groups of survivors and nonsurvivors were obtained by orthogonal contrasts, displayed as Log of Lactate, as described previously by Schall ${ }^{7}$. The significance level was set at 0.05 . All statistical analyses were performed using SAS software version 9.2 (SAS Institute Inc., Cary, NC, USA).

\section{Results}

Forty-four (38 males and 10 females, with a mean age of $52.2 \pm 8.9$ years) patients survived at least 1 month after the surgery, whereas 10 (6 males and 4 females, with a mean age of $49.8 \pm 14.9$ years) died during this period. The overall mortality was $17.3 \%$. The most common indications for liver transplantation were alcohol-, viral-, hepatocarcinoma-induced cirrhosis and primay biliary cirrhosis. The APACHE II score was $14.4 \pm 6.6$ and $22.2 \pm 10.1$ for survivors and nonsurvivors $(\mathrm{p}<0.05)$, respectively. The death risk was $17.0 \pm 15.8$ and $40.2 \pm 32.4$ for survivors and nonsurvivors, respectively $(\mathrm{p}<0.05)$. The MELD post-OLT was $23.4 \pm 6.6$ and $31.4 \pm 5.7$ for survivors and nonsurvivors, respectively $(\mathrm{p}<0.05)$. Demographic, clinical (including serum creatinine, bilirubin and INR), and etiologic data for all the OLT patients (survivors and nonsurvivors) are listed in Table 1. 
TABLE 1 - Demographic, clinical and etiologic data of patients submitted to ortothopic liver transplantation.

\begin{tabular}{ccc}
\hline $\begin{array}{c}\text { Patients } \\
(\mathbf{n}=\mathbf{5 8})\end{array}$ & $\begin{array}{c}\text { Survivors } \\
(\mathbf{n}=\mathbf{4 8})\end{array}$ & $\begin{array}{c}\text { Nonsurvivors } \\
(\mathbf{n}=\mathbf{1 0})\end{array}$ \\
\hline Sex (M/F) & $38 / 10$ & $6 / 4$ \\
Age (years) & $52.2 \pm 8.9$ & $49.8 \pm 14.9$ \\
APACHE II & $14.4 \pm 6.6$ & $22.2 \pm 10.1^{*}$ \\
Death Risk (\%) & $17.0 \pm 15.8$ & $40.2 \pm 32.4^{*}$ \\
Creatinine (mg/L) & $1.6 \pm 1.3$ & $1.8 \pm 1.1$ \\
Bilirubin (mg/L) & $4.7 \pm 3.2$ & $10.7 \pm 11.6^{*}$ \\
INR & $2.3 \pm 0.9$ & $6.4 \pm 5.2^{*}$ \\
MELD post-OLT & $23.4 \pm 6.6$ & $31.4 \pm 5.7^{*}$ \\
Hepatocellular Carcinoma & 9 & 4 \\
Alcoholic Cirrhosis & 19 & 2 \\
Hepatitis Virus B & 1 & 0 \\
Hepatitis Virus C & 11 & 1 \\
Primary Biliary Cirrhosis & 4 & 2 \\
Others & 4 & 1 \\
\hline
\end{tabular}

*Values expressed as mean $\pm \mathrm{SD}(\mathrm{mmol} / \mathrm{L}),{ }^{* *} \mathrm{p}<0.05$

The values for serial blood lactate levels (lactate and Log of Lactate) between survivors and nonsurvivors, as summarized in Table 2 and depicted in Figure 1. This parameter became significantly different between survivors and nonsurvivors just before the end of the surgery (L7), thereby remaining the rest of the study (L8 to D2) $(\mathrm{p}<0.05)$.
TABLE 2 - Serial lactate blood levels (L) of patients survivors and nonsurvivors of liver Transplantation (Preoperative and Perioperative phases, 24 and 48 hours after the surgery).

\begin{tabular}{|c|c|c|c|}
\hline TIME & VARIABLE & SURVIVORS & NONSURVIVORS \\
\hline $\begin{array}{l}\text { L1 - Baseline } \\
\text { (Preoperative) }\end{array}$ & $\begin{array}{c}\text { Lactate* }^{*} \\
\text { Log of Lactate }\end{array}$ & $\begin{array}{l}1.67 \pm 0.52 \\
0.47 \pm 0.31\end{array}$ & $\begin{array}{l}1.73 \pm 0.71 \\
0.47 \pm 0.43\end{array}$ \\
\hline $\begin{array}{l}\text { L2 (Beginnig of } \\
\text { the Surgery) }\end{array}$ & $\begin{array}{c}\text { Lactate } \\
\text { Log of Lactate }\end{array}$ & $\begin{array}{l}2.59 \pm 0.89 \\
0.89 \pm 0.38\end{array}$ & $\begin{array}{l}2.16 \pm 0.89 \\
0.69 \pm 0.42\end{array}$ \\
\hline L3 & $\begin{array}{c}\text { Lactate } \\
\text { Log of Lactate }\end{array}$ & $\begin{array}{l}3.85 \pm 1.08 \\
1.31 \pm 0.28\end{array}$ & $\begin{array}{l}3.31 \pm 1.54 \\
1.08 \pm 0.56\end{array}$ \\
\hline L4 & $\begin{array}{c}\text { Lactate } \\
\text { Log of Lactate }\end{array}$ & $\begin{array}{l}4.49 \pm 1.41 \\
1.45 \pm 0.32\end{array}$ & $\begin{array}{l}4.93 \pm 2.38 \\
1.50 \pm 0.45\end{array}$ \\
\hline L5 & $\begin{array}{c}\text { Lactate } \\
\text { Log of Lactate }\end{array}$ & $\begin{array}{l}5.18 \pm 1.65 \\
1.59 \pm 0.34\end{array}$ & $\begin{array}{l}6.34 \pm 3.07 \\
1.75 \pm 0.45\end{array}$ \\
\hline L6 & $\begin{array}{c}\text { Lactate } \\
\text { Log of Lactate }\end{array}$ & $\begin{array}{l}5.10 \pm 1.97 \\
1.55 \pm 0.40\end{array}$ & $\begin{array}{l}6.98 \pm 4.30 \\
1.81 \pm 0.51\end{array}$ \\
\hline L7 & $\begin{array}{c}\text { Lactate } \\
\text { Log of Lactate }\end{array}$ & $\begin{array}{l}4.87 \pm 2.40 \\
1.48 \pm 0.47\end{array}$ & $\begin{array}{l}7.37 \pm 4.45^{* *} \\
1.84 \pm 0.61\end{array}$ \\
\hline $\begin{array}{l}\text { L8 (End of } \\
\text { the surgery) }\end{array}$ & $\begin{array}{c}\text { Lactate } \\
\text { Log of Lactate }\end{array}$ & $\begin{array}{l}4.38 \pm 2.31 \\
1.38 \pm 0.43\end{array}$ & $\begin{array}{l}8.56 \pm 5.55^{* *} \\
1.99 \pm 0.58\end{array}$ \\
\hline $\begin{array}{l}\text { LD1 (24 hours } \\
\text { after surgery) }\end{array}$ & $\begin{array}{c}\text { Lactate } \\
\text { Log of Lactate }\end{array}$ & $\begin{array}{l}2.61 \pm 1.96 \\
0.80 \pm 0.54\end{array}$ & $\begin{array}{l}9.13 \pm 9.81 * * \\
1.71 \pm 1.07\end{array}$ \\
\hline $\begin{array}{l}\text { LD2 (48 hous } \\
\text { after surgery) }\end{array}$ & $\begin{array}{c}\text { Lactate } \\
\text { Log of Lactate }\end{array}$ & $\begin{array}{l}2.26 \pm 2.00 \\
0.64 \pm 0.53\end{array}$ & $\begin{array}{c}10.65 \pm 12.52^{* *} \\
1.74 \pm 1.19\end{array}$ \\
\hline
\end{tabular}

*Values expressed as mean $\pm \mathrm{SD}(\mathrm{mmol} / \mathrm{L}), * * \mathrm{p}<0.05$

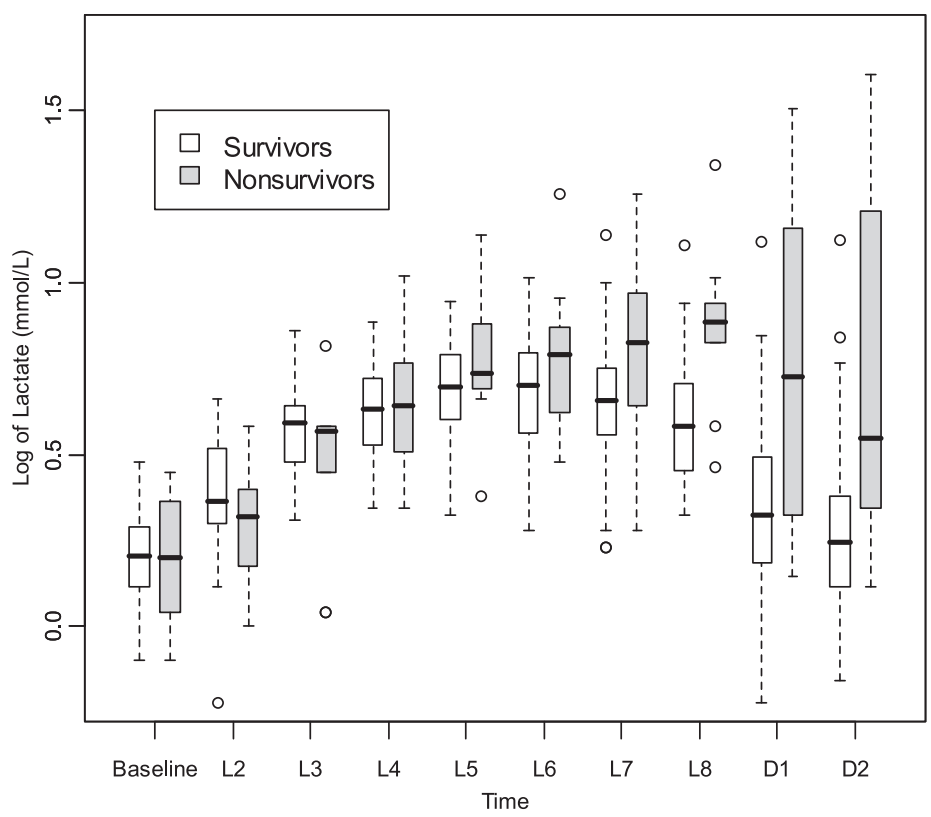

FIGURE 1 - Boxplot of serial lactate blood levels (represented as Log of Lactate), distributed by group (survivors and nonsurvivors) and time interval. 
The AUC was $0.726(95 \% \mathrm{CI}=0.593-0.835)$ for APACHE II $(\mathrm{p}=0.02) ; 0.770(95 \% \mathrm{CI}=0.596-0.849)$ for blood lactate levels $(\mathrm{L} 7-\mathrm{L} 8)(\mathrm{p}=0.03) ; 0.814(95 \% \mathrm{CI}=0.690-0.904)$ for MELD postOLT $(\mathrm{p}<0.01) ; 0.550(95 \% \mathrm{CI}=0.414-0.651)$ for creatinine $(\mathrm{p}=$ $0.64) ; 0.705(95 \% \mathrm{CI}=0.571-0.818)$ for bilirubin $(\mathrm{p}=0.05)$ and $0.774(95 \% \mathrm{CI}=0.654-0.873)$ for INR $(\mathrm{p}=0.02)$, as demonstrated in Table 3. It was observed that the AUC for MELD post-OLT was higher than the AUC for other parameters.

TABLE 3 - Area under the curve (AUC) of receiving operator characteristics (ROC) for different predictors at ICU admission.

\begin{tabular}{cccc}
\hline Variable & AUC & $\mathbf{9 5 \% C I}$ & $\boldsymbol{P}$ value \\
\hline APACHE II & 0.726 & $0.593-0.835$ & 0.02 \\
Blood Lactate & & & \\
L7-L8 (mmol/L) & 0.770 & $0.596-0.849$ & 0.03 \\
MELD post-OLT & 0.814 & $0.690-0.904$ & $<0.01$ \\
Creatinine (mg/dL) & 0.550 & $0.414-0.651$ & 0.64 \\
Bilirubin (mg/dL) & 0.705 & $0.571-0.818$ & 0.05 \\
INR & 0.774 & $0.645-0.873$ & 0.02 \\
\hline
\end{tabular}

\section{Discussion}

The main goal of the present investigation was to carry out a follow-up on a series of recently published investigations on the exhaustive search for a parameter capable of predicting the early mortality (up to one month) of patients submitted to OLT. The examination of these references of the current literature trends concerning this topic, point out to the fact that the physiologic and/or clinical factors concerning severity at ICU arrival and comorbidities present before the surgery are a relevant issue. In this sense, the methodology and results of the present investigation are similar to those that employed different parameters, acting as predictors, published elsewhere ${ }^{4,8,9}$. However, current indexes are unable to accurately predict which patients will have a high probability of posttransplant survival. For this reason, the search for a prognostic factor to predict early mortality of patients submitted to OLT still remains. Among the parameters most frequently utilized for prediction of early mortality in OLT patients, the perioperative blood lactate levels, the APACHE II, the INR and the MELD post-OLT seem to be more precise.

The metabolic fate of lactate metabolism has been challenging scientists around the world throughout the past decades. Indeed, more than being considered as an end-product of anaerobic glycolysis, indicator of tissue hypoperfusion and hypoxia, because of an imbalance between oxygen supply and oxygen demand, this metabolite has a particular role in different metabolic pathways. This includes insulin release, regulation of plasma glucose and modulation of energy homeostasis ${ }^{10}$. The serial blood lactate monitoring has been assessed in the critically ill patient in many situations ${ }^{11}$ demonstrated that persistent elevation of blood lactate level in septic patients can be a reliable predictor of multiple organ failure syndrome and poor prognosis. Thus, in the ICU setting the study of the behavior of this metabolite in severe sepsis or septic shock is gaining terrain even more, since the reduction of elevated blood lactate level is considered to be the primary target of the treatment of the critically ill patient ${ }^{12-14}$.

The hepatic tissue has a great capability to convert lactate to pyruvate through lactate deshydrogenase and then into glycogen. Consequently, the impairment of liver function after the graft transplantation provoked by systemic hypoperfusion, hypoxia and acidosis are responsible for a low clearance of lactate, especially after the reperfusion. Therefore, in the case of liver transplantation, the perioperative blood lactate levels had shown a close relationship with survival rates shortly after ICU admission. In this context, De Gasperi et al. ${ }^{1}$ recorded the blood lactate levels and prothrombin times in all perioperative phases of 53 postnecrotic cirrhotic patients submitted to OLT. These authors observed an increase of lactate levels during the preanhepatic and anhepatic stages, followed by a peak of lactate level after the graft revascularization $(>4 \mathrm{mmol} / \mathrm{L})$, associated to a higher prothrombin time in some patients, becoming significant after the end of the surgery. It was stated that more than an absolute value, the blood lactate appears to be a useful indicator of hepatic metabolic recovery of its functional capabilities in the immediate postoperative period of OLT. Additionally, Nishimura et al. ${ }^{2}$ conducted a study in 15 living donors liver transplantation and it was observed that the lactate clearance is associated to the size of the graft. The proposal of this investigation is that the lactate elimination is a reliable independent predictor of hepatic function and early mortality after liver transplantation.

Despite the importance of lactate metabolism playing a pivotal role as a probe of hepatic functioning, some others parameters may reflect the clinical condition of the patient at ICU admission and predict early mortality of OLT patients. However, it should be emphasized that a definitive index for the accurate prediction of survival rate and/or early mortality after OLT has not yet been developed.

In this particular task, a number of attempts using different approaches to explore this matter were undertaken. Volk et al. ${ }^{8}$ verified that the Charlson comorbidity index can be applied for prediction of mortality after liver transplantation, because the 
most frequently detected comorbidities in the patients with poor outcome were coronariopathy, diabetes, chronic obstructive lung diseases, autoimmune diseases, and need for renal replacement therapy. On the other hand, the MELD score could also be used to predict early mortality after OLT, since this score is based on three physiological serum variables (creatinine, bilirubin and INR). Siniscalch et $a l .{ }^{9}$ demonstrated that patients with and without posttransplantation complications had slightly different mean MELD scores, equal to 22.8 and 17.8, respectively. In a previous study carried out in our ICU, we observed that the mean MELD pre-OLT score was 20.1 and 19.2 for survivors and nonsurvivors, respectively. The prediction of early mortality was not satisfactory, since the area under the ROC curve was only 0.50 . Interestingly, when this index was calculated within the first 24 postoperative hours (MELD post-OLT), the mean values found for survivors and nonsurvivors presented significant differences $(23.3 \pm 6.8$ and $31.0 \pm 5.9$, respectively) and the area under the ROC curve was $0.74^{4}$.

The APACHE II system is one of the prognostic indexes most employed for correlation between expected/observed mortality and risk of death in critically ill patients in ICUs worldwide. This score is based in physiologic measurements, age and comorbidities. Karvellas et al. ${ }^{15}$ observed that a combination of the MELD and APACHE II scores was useful for prediction of bacteremia in patients with acute liver failure. In a representative number of patients, it was showed that $36 \%$ of them presented bacteremia (mainly gram negative bacteria). The authors also demonstrated that high MELD and APACHE II scores were correlated with length of mechanical ventilation, need for dialysis, and lower survival.

Nevertheless, our data provide a different perspective, since we observed a close profile among the various parameters studied when MELD post-OLT, INR, serial blood lactate levels and APACHE II were utilized as predictors, demonstrating the contribution of these parameters to the prediction of early mortality of OLT patients. Data from the present study point to the fact that these parameters can be employed in this situation, particularly when these data were confirmed by the ROC curve, which furnished area under the curve equal to $0.814,0.774,0.770$ and 0.726 , respectively.

\section{Conclusions}

Among the studied parameters, it seems that the MELD post-OLT performed better in predicting early mortality of patients after orthotopic liver transplantation. Moreover, data from our present study should make transplant team members aware of the fact that the use of parameters, such as perioperative blood lactate levels, APACHE II, INR together with MELD post-OLT, might indicate which patients are at higher risk of early mortality (up to 30 posttransplantation days). Further investigations should be encouraged to reproduce these findings.

\section{Acknowledgments}

We are thankful to Ronaldo Vicente Martins for his technical assistance in data acquisition and Davi Casale Aragon for statistical analysis procedures.

\section{References}

1. De Gasperi A, Mazza E, Corti A, Zoppi F, Prosperi M, Fantini G, Scaiola A, Colella G, Amici O, Notaro P, Rocchini A, Ceresa F, Roselli E, Grugni MC. Lactate blood levels in the perioperative period of orthotopic liver transplantation. Int J Clin Lab Res. 1997;27(2):123-8.

2. Nishimura A, Hakamada K, Narumi S, Totsuka E, Toyoki Y, Ishizawa Y, Umehara M, Yoshida A, Umehara Y, Sasaki M. Intraoperative blood lactate level as an early predictor of initial graft function in human living donor liver transplantation. Transplant Proc. 2004;36:2246-8.

3. Shin YH, Yu SK, Kwon CH, Ko JS, Gwak MS, Kim GS. The comparison of the perioperative changes in lactate and prothrombin time between deceased versus living donor liver transplantation. Transplant Proc. 2010;42:4151-3.

4. Basile-Filho A, Nicolini EA, Auxiliadora-Martins M, AlkminTeixeira GC, Martinez EZ, Martins-Filho OA, Castro e Silva O. Comparison of acute physiology and chronic health evaluation ii death risk, child-pugh, charlson, and model for end-stage liver disease indexes to predict early mortality after liver transplantation. Transplant Proc. 2011;43:1660-4.

5. Knaus WA, Draper EA, Wagner DP, Zimmerman JE. APACHE II: a severity of disease classification system. Crit Care Med. 1985;13:818-29.

6. Zweig MH, Campbell G. Receiver-operating characteristic (ROC) plots: a fundamental evaluation tool in clinical medicine. Clin Chem. 1993;39:561-77.

7. Schall R. Estimation in generalized linear models with random effects. Biometrika. 1991;78:719-27.

8. Volk ML, Hernandez JC, Lok AS, Marrero JA. Modified Charlson comorbidity index for predicting survival after liver transplantation. Liver Transpl. 2007;13:1515-20.

9. Siniscalchi A, Cuachetti A, Toccaceli L, Spiritoso R, Tommasoni E, Spedicato S, Dante A, Riganello L, Zanoni A, Cimatti M, Pierucci E, Bernardi E, Miklosova Z, Pinna AD, Faenza S. Pretransplant model for end-stage liver disease score as a predictor of postoperatve complications after liver transplantation. Transplant Proc. 2009;41:1240-42.

10. Sola-Penna M. Metabolic regulation by lactate. IUBMB Life. 2008;60:605-8.

11. Bakker J, Gris P, Coffernils M, Kahn RJ, Vincent JL. Serial blood lactate levels can predict the development of multiple organ failure following septic shock. Am J Surg. 1996;171:221-6.

12. Jansen TC, van Bommel J, Bakker J. Blood lactate monitoring in 
critically ill patients: a systematic health technology assessment. Crit Care Med. 2009;37:2827-39.

13. Nichol AD, Egi M, Pettila V, Bellomo R, French C, Hart G, Davies A, Stachowski E, Reade MC, Bailey M, Cooper DJ. Relative hyperlactatemia and hospital mortality in critically ill patients: a retrospective multi-centre study. Crit Care. 2010;14:R25.

14. Jansen TC, van Bommel J, Schoonderbeek FJ, Sleeswijk Visser SJ, van der Klooster JM, Lima AP, Willemsen SP, Bakker J; LACTATE study group. Early lactate-guided therapy in intensive care unit patients: a multicenter, open-label, randomized controlled trial. Am J Respir Crit Care Med. 2010;182:752-61.

15. Karvellas CJ, Pink F, McPhail M, Austin M, Auzinger G, Bernal W, Sizer E, Kutsogiannis DJ, Eltringham I, Wendon JA. Bacteremia, acute physiology and chronic health evaluation ii and modified end-stage liver disease are independent predictors of mortality in critically ill nontransplanted patients with acute on chronic liver failure. Crit Care Med. 2010;38:121-6.

\section{Correspondence:}

Anibal Basile-Filho

Divisão de Terapia Intensiva, Departamento de Cirurgia e

Anatomia

Faculdade de Medicina de Ribeirão Preto, Universidade de São

Paulo

Avenida Bandeirantes, 3900

14048-900 Ribeirão Preto - SP Brasil

Tel.: (55 16)3602-2409

abasile@,fmrp.usp.br

Received: May 18, 2011

Review: July 20, 2011

Accepted: August 19, 2011

Conflict of interest: none

Financial source: none

${ }^{1}$ Research performed at Department of Surgery, Division of Intensive Care and Special Liver Unit, Riberao Preto Medical School, University of Sao Paulo (FMRP-USP), Brazil.

Presented at the XII National Congress on Experimental Surgery of the Brazilian Society for the Development of Research in Surgery-SOBRADPEC 2011 October 26-29, Ribeirao Preto-SP, Brazil. 